\title{
Accountability and service quality in public service in Israel
}

Yehuda ELIYA $^{1}$

Abstract
In the last decades we are witnessing to a turn in the interaction between the
citizen, as clients, and the public administration, mainly in the level of citizens,
increased expectations about the quality delivered by public service organisations. The
citizen is asking for quality service with accountability of the professional factors in
public organizations. This article will discuss two main phenomena in public service
today: accountability and service quality.

Keywords: public service, service quality, service quality climate, accountability, efficiency, performance

Jel classification: G20, G 28, G 29

DOI: 10.24818/RMCI.2018.3.289

\section{Introduction}

By the end of the $20^{\text {th }}$ century has started a change in the perception of public service role in western countries. The new perception that was developed was called "The Service Revolution". In Britain the revolution was called "Value for Money" and in the USA "Customer Driven Government". The common of all was defining citizens as "customers" and demanding public organizations give improved services similar to those that are given by the business organizations. Those perceptions were widened and influenced a lot on reforms in public service in Britain, New Zealand, Australia, USA and Canada (Evans \& Lindsay, 2002).

Service, according to quality perception, has to respond the need of the clients it addresses to. Public service is under constant high public pressure to improve its performance, mostly by economic constraints due to its diminishing public resources sources and increased commitment to accountability towards the citizens (Wisniewski, 2001).

"Total quality" is based on three principals: focusing on client and stockholders, participation and team work of everybody in the organization, focusing on the process and supporting it by constant improvement and study (Schneider e.a, 2009). Organization that is committed to total quality is acting at three levels: organization level, process level and performance level. At the level of the whole organization, its obligation is to daily looking for client's attention, questions and making them the basis of setting its goals. Second, at the process level, the main target is to ensure efficient activity coordination between departments of the organisation. Thirdly, regarding the performance level it is

\footnotetext{
${ }^{1}$ Yehuda Eliya' $\mathrm{PhD}$ candidate' West University of Timisoara
} 
fundamental to set productivity standards that are based bon service quality and responding the client's needs. These standards include demands to punctuality, innovation, perfection, availability and price (Evans \& Lindsay, 2002).

Government ministries in Israel are not a model of high level of service and have tradition of lack of consideration for the service recipients' needs for many years (Gal Nur, 2007). In 1989 the Kovarsky committee was appointed to undertake a comprehensive examination of public service. In its recommendation was written that must be a turn in the interaction between the citizen and the public administrationin order to improve the services provided by public institutions to Israeli citizen. A development in consumer awareness of the Israeli public has started since and it was based on citizen legal rights and not on kindness or favoritism. In the years 1996-1996 a trial of reform in public service was made according to the "citizen charter" British reform model. In this reform the state commission established the department of quality and excellence in public service and started to perform the "quality service convention" in all government ministries. This convention detailed the indicators to service quality, rights of service recipient, respond time and the right to appeal. The examination mean was a feedback from service recipients. The goal - to implement the perception by which citizens are service recipients on government ministries and are entitled to qualitative and equitable service (Gal Nur, 2007).

In random researches done between 2001-2014 (Vigoda\&Mizrhai, 2008; Vigoda -Gadot\& Mizrahi, 2014) that engaged with the image of service quality in the eyes of its recipients it was found that the level of satisfaction and trust of citizens in public service was medium.

\section{The climate of quality service in public organizations}

Service climate in the public organization reflects the institutional orientation of activities that support giving better service to clients or citizens (Schneider et al. 2009). We agree that "an organization that is committed to giving excellent service to its clients has to establish working methods and systems that encourage and reward workers for giving qualitative service - "service climate" if you want" (Panisa\& Patterson, 2011). Schneider et al. defined organizational climate as the meaning given by the employees to the policy, working methods, processes and behavior that are supported and rewarded by the organization. Accordingly, service climate was defined by (Schneider et al., 1998) as mutual perceptions of employees and refer to methods, processes and behavior types, which are rewarded and valued in client service and service quality. The service climate is a general trend to service delivery that emphasizes human resource management methods, definition of administrative client aimed priorities (Dean \&Rainnie, 2009).

Schneider \& Bowen (1993) defined in wider detail the organizational climate through four main dimensions: (1) Management behavior - behavior of managers in managing chain referring planning, organization and service 
management; (2) Systematic support -supporting service trough marketing, suitable man power and activating the systems in the organization; (3) Targeting and retaining clients -intra-organizational behavior that presents the importance of clients to organization's departments; (4) Logistic support - availability of tools, equipment and stocks required to service delivery.

An organization with a good service climate rewards his employees that are excellent in their service (Vigoda-Gadot\&Meiri, 2008). The organizational service climate is paramount to the functional dimension of service (Mayer, Ehrhart\& Schneider, 2009). Organizations that want to give qualitative service are required to provide and maintain the service climate in the organization (Johnson, 1996).

Many researchers (Schneider \& Bowen, 1993; Schneider et. al, 2009; Dean \& Rainnie, 2009) claim that service climate is based on basic support foundations given by the organization through resources, training, administrative approaches and assistance required to performing effective performance. Walker (2007) claims that examination of the quality level of service climate is based on the way the organization operates its working methods and behavior to get qualitative service. It is reflected in management support to service providers, maintenance of skilled teams, employees training to widen their knowledge in service area and also recognition and reward for good service performing. The service climate gives employees in the organization a strong message about the important issues for the organization, the employee's expected attitudes and behaviors (Little \& Dean, 2006). The perception about service climate is especially major in service sector in which service quality is in first priority (Poujol, 2009).

The influence of service climate on the organization's productivity in service area is discussed by Schneider et al. (2009) that claim that the meaning of service climate given by employees in their work strongly influence the attention they give to service quality. Consequently, clients experience the behavior of service providers that are influenced by the organizational climate. As a result of these service experiences, the organization's clients are coming to conclusions about the quality of the service they got, and these conclusions influences their satisfaction towards the organization..

Regarding the development of service climate in public sector, there is an increasing trend currently to change the perception that was accepted in old bureaucratic organizations (Vigoda- Gadot, 2008). This change is reflected in the entrance of the public sector in a new era that is characterized by increased marketing orientation, organizational flexibility, efficiency and responding to the citizens' needs. In addition, the awareness to the ability to control the functioning of the service to the public through quantitative control indicators for examining satisfaction and the image of the public organization in the public's eyes has risen in the last years(Vigoda-Gadot\&Drory,2016).

Wiley, Pugh \& Dietz (2004) claim that as higher the interaction between the organization and its clients the more important is the service climate as an influencing factor of the perceptions and attitudes of the organization's service 
recipients. When we examine the change that organizations and public institutes have implemented in their management and service perception during the last years, implementing the new public management (NPM), we understand that there is no way back to the traditional public service. The perception of the way the public sector has to deal with service given to the public has to be characterized by business vision like the one that prevails in the top perfoming business organizations from the private sector.

\section{Accountability}

In research literature there is still no satisfactory interpretation for the operative meaning of the term accountability in public sector. In most cases, accountability is mentioned as a term or principle referring to a situation when something goes wrong, when somebody try to determine a cause or point an accusing finger to the cause of failure (Conners, Smith \& Hickman, 1994). Also, accountability is defined as "individual's awareness to the responsibility he might have on judgment of decision making processes and / or the performance of decisions he made" (Tetlock, 1985). Accountability is also perceived as the "transferable responsibility between middle echelons to a low echelon" (De HavenSmith \&Jenne, 2006). According to Schillemans (2010) accountability involves also responding to senior echelons in the organization's management or bureaucratic chain, to the organization's clients and the environment in which the role holder works. This approach is taking into account multiple stakeholders towards the individual is accountable for, clients being a major stakeholder of any organization.

In literature we identified different types of accountability according to the environment in which people work due to their profession, agreements between them and the service recipients and more. Among the types, we may find common accountability types, as bureaucratic/hierarchic accountability, professional accountability, market accountability (Darling-Hammond \&Ascher, 1991) and political and legal accountability ((Romzek\&Dubnick, 1994).

Erkkia (2007) refers to accountability in a similar way. In addition, he claims that the openness component embedded in processes of public decision and public policy making is a significant and integral part of the accountability concept.

Romzek\& Ingraham (2000) claim that accountability in its most basic sense refers to the ability to respond to any factor about expected performance. Roberts (2002) presents five aspects of accountability in public organization: (1)Transparency (2)Liability (3) Controllability (4) Responsibility and (5) Responsiveness.

Eun \&Wook (2010) refer to the accountability term as involving four accountability areas. The first is the "hierarchic / bureaucratic" accountability, that points on supervisors tight supervision through use of rules and regulations, training through supervision and fixed standards to performance measuring. The second type is "legal accountability" which reflects an external view, both comprehensive and detailed, of the performance, which is aimed to preserve the 
contractual relationship in the organization. The third one, is the "professional accountability", defined as the expectation that employees in the organization will work based on their expertise, on the required professional norms and standards. "Political accountability", the fourth type refers to the organization's responsiveness to its main stakeholders, i.e. clients, government, and community groups and individual citizen.

Bolton (2003) claims that the public sector, like the private sector, is influenced by two main processes: the first being technological progress and the second, is public clients' expectations. Expectations changed when clients became more educated, having more knowledge and higher awareness to their surroundings. According to him, most of business processes that were improved due to new technology exist also in the public sector. The world expects that the public sector and nonprofit organizations will bear greater responsibility in their use of public money, public resources. The public sector's performance is lower than the private sector's performance and the public sector workers often claim that the reason for it is the poorer resource allocation than in the private sector. $\mathrm{He}$ claims that the truth is combined by those two claims and other additional components.

We consider that essential for the success of public sector organizations is the level of mission performance. Completing the mission includes additional factors in terms of being efficient, be responsible for public money and in terms of offering satisfactory service to clients. Lately, the expectation raises more and more and public organizations are forced to embrace methods of performance improvement that are implemented in private sector to prove accountability of their employees.

Some of the success factors are supervised by governmental supervisors and internal auditor etc. and some are supervised by the service recipient public. Competition is an improvement motivating factor in offices that provide services and are in competition with private sector organizations. Although, for many organizations in public sector competition does not exist because governments do not allow private organizations to offer competing service to services given by public organizations.

Nowadays, legal precedents, statutory decisions, regulations and procedures officially set external mechanisms to guarantee accountability of managers in public service (Bertelli, 2004). Accountability is the ability to respond the supervisors or their representatives and the responsibility of each public representative (Cooper, 1990). Accountability is the duty of public organizations to serve higher authority which is the public trust because it is the source of the authority of those organizations. We may find standards of accountability in the rules manuals and procedures. These are standards that are expressing the clear expectations the public has of the public officers. An indirect way for placing those expectations is expressed in implicit criticism of tax payers, clients, money donors, media and other stakeholders (Dubnick, 2005). 


\section{Service quality and accountability}

Accountability necessarily involves standards and end parties. The key components identified in definitions of accountability are the following: justification, reporting side and an audience that receive the report, feedback, rewards and sanctions. Those definitions even imply the existence of agreed goals or standards by which performance and results are measured.

A main subject in the term accountability at individual level is its context to performance in executing work and its results. The term accountability is embodied in performance evaluation and feedback of performance is a mechanism in which the audience transmits its reaction to the reporting side. The employees' tend to accountability is the will to meet the expectations, strong feelings of accountability and usually even significant influence on the actions of specific individual in the organization. Therefore, the service quality is a feedback to meeting the expectations of clients to get a good service. Employees that feel accountable will be aware of the required means to achieve optimal performance of their work. Their working methods and its results will be, relatively, visible and transparent and they will get the appreciation and expect it (Rosenblatt, 2006).

There are many researches in the subject of accountability mainly in the area of public education. Some examine the connection between accountability and effectiveness. These researches show that accountability increases teachers' effectiveness and therefore it is important in educational organisations. In the world (,Jones et al, 1999; O'Day, 2001) and in Israel (Rosenblatt \&Shimoni, 2001) systems of accountability were developed within researches in order to examine which components of accountability will lead to effectiveness. Accountability was found as predicting high levels of involvement and civic behavior (Hall et al, 2007). O'Day (2002) has found that accountability brought an improvement of students' learning skills and, therefore, an improvement of students' performance. As a result of it public schools performance is improved and the clients / students satisfaction raises.

Based on these considerations, we have formulated three hypothesis regarding the relation between accountability and the climate of quality of service in Israeli public organizations, such as 1) There is a positive relation between responsibilities and the climate of quality of service, 2) there is a positive relation between the accountability of employee and the climate of quality of service, and 3 ) there is a positive relation between the organization's accountability and the climate of quality of service.

\section{Conclusions}

Accountability according to Schillemans (2010) involves responding to senior echelons in the organization's management or bureaucratic chain, to the organization's clients and the environment in which the role holder works. By the last years, the level of expectations of citizens from the public sector rose and

Review of International Comparative Management

Volume 19, Issue 3, July 2018 
service quality is a feedback of public sector's meeting the expectations and providing better service. However, since public service quality cannot be just a "lip service", public organizations must create climate of service quality that supports a qualitative service on one hand and accountability for it on the other hand.

\section{Bibliography}

Bertelli, A. M.. Strategy and Accountability: Structural Reform Litigation and Public Management. Public Administration Review. 64. (1). pp. 28-42. 2004

Bolton, M. Public Sector Performance Measurement: Delivering Greater Accountability. Work Study, 52, 1, 20-24. 2003

Cooper, T. The responsible administrator: an approach to ethics for the administrative role. San Francisco: Jossey-Bass Publishers. 1990

Conners, R., Smith, T. \& Hickman, C. (1994). The Oz Principle: Getting Results Through Individual and Organizational Accountability. Prentice Hall, NJ.

Darling-Hammond, L \&Ascher, C. Accountability mechanism in big city school systems. ERIC Clearinghouse on Urban Education New York, Digest 17. 1991

Dean, A. M. \&Rainnie, R. Frontline Employees' Views on organizational Factors That Affect the Delivery of Service Quality in Call Centers. The Journal of Services Marketing. 23. (5). Pp. 326- 337. 2009

De Haven-Smith, L. \&Jenne, K. C., II. Management by Inquiry: A Discursive Accountability System for Large OrganizationsFull Text Available. Public Administration Review. (66). (1). Pp. 64-76. 2006

Dubnick, M. Accountability and the Promise of Performance: In Search of the Mechanisms. Public Performance and Management Review. 28. (3). Pp. 376-417. 2005

Evans, J.R. \& Lindsay, W.M. The management and control of quality, 5th edition. Cincinnati, Ohio: South-Western. 2002

Eun Kim, S., \&Wook Lee, J. Impact of Competing Accountability Requirements on Perceived Work Performance. The American Review of Public Administration. 40. 1. Pp. 100-118. 2010

Erkkila, T. Governance and Accountability: A Shift in Conceptualisation.1. Public Administration Quarterly. 31. Pp. 1-38. 2007

Gal Nur, Y. The public sector: development, structure, function and reforms. Jerusalem. Hebrew University. 2007

Hall, A. T., Bowen, M. G., Ferris, G. R., Royle, M. T. \& Fitzgibbons, D. E. The accountability lens: A new way to view management issues. Business Horizons. 50. Pp. 405-413. 2007

Johnson, J. W. Linking employee perceptions of service climate to customer satisfaction. Personnel Psychology. 49. (4). Pp. 831-851. 1996

Review of International Comparative Management Volume 19, Issue 3, July $2018 \quad 295$ 
Jones, G. M., Jones, B. D., Hardin, B., Chapman, L., Yarbrough, T. \& Davis, M. The impact of high stakes testing on teachers and students, Phi Delta Kappan, 81, 3, 199-203. 1999

Little, M. L. \& Dean, A. M.. Links Between Service Climate, Employee Commitment and Employees' Service Quality Capability. Managing Service Quality. 16. (5). Pp. 460- 476. 2006

O'Day, J. Complexity, accountability, and school improvement. Harvard Educational Review, 72, 3, 293-329. 2002

Panisa, M. \& Patterson, P. G. The Impact of Service Climate and Service Provider Personality on Employees' Customer-Oriented Behavior in a High- Contact Setting. The Journal of Services Marketing. 25. (2). Pp. 101- 113. 2011

Roberts, N. C. Keeping Public Officials Accountable through Dialogue: Resolving the Accountability Paradox. Public Administration Review. 62. (6). Pp. 658-669. 2002

Romzek, B. S. \&Dubnick, M. J. Accountability in the Public Sector: Lessons from the Challenger Tragedy. Public Administration Review. 47. (3). Pp. $227-$ 2381987

Romzek, B.S. \& Ingraham, P. W. (2000). Cross Pressures of Accountability: Initiative, Command, and Failure in the Ron Brown Plane Crash.Public Administration Review. 60. (3). Pp. 240-253. 2000

Rosenblatt, G. Shimoni, P. Teachers are responsible for teaching: an experimental study in the field of physical education teachers. Studies in Education, 5, pp 256-229. 2001

Rosenblatt, Z. The Construction and Cross-Validation of a Self-report Measure of Teacher Accountability, Presented at the annual meeting of the American Educational Research Association, San Francisco. 2006

Schillemans, T. Redundant Accountability: The Joint Impact of Horizontal and Vertical Accountability on Autonomous Agencies. Public Administration Quarterly. 34. (3). Pp. 300-337.2010

Schneider, B. \& Bowen, D. E. he Service Organization: Human Resources Management Is Crucial. Organizational Dynamics. 21. (4). Pp. 39-52. 1993

Schneider, B., Chung, B. \&Yusko, K. P. Service Climate for Service Quality. American Psychological Society. 2 (6). Pp. 197-200.1993

Schneider, B., White, S.S. \& Paul, M.C. Linking Service climate and customer perceptions of Service quality: test of a casual model. Journal of Applied Psychology. 83. (2). Pp. 150-63. 1998

Schneider, B., Ehrhart, M. G., Mayer, D. M., Saltz J. L. \& Miles-Jolly, K. Understanding organization-customer links in Service settings. Academy of Management Journal. 48. (6). Pp. 1017-1032. 2005

Schneider, B., Macey, W. H., Lee, W. C. \& Young, S. A. Organizational Service Climate Drivers of the American Customer Satisfaction Index (ACSI) and Financial and Market Performance. Journal of Service Research. 12. (1). pp. 3-14. 2009

Tetlock, P. E. Accountability: The neglected social context of judgment and 
choice. Research in Organizational Behavior. 7. Pp. 297-332. 1985

Vigoda-Gadot E. \&Drory A. (Eds.) Handbook of Organizational Politics: Looking Back and to the future. Cheltenham, UK; Edwars Elgar. 2016

Vigoda-Gadot, E. \& Mizrahi, S. Public Sector Management and the Democratic Ethos: A 5-Year Study of Key Relationships in Israel. Journal of Public Administration Research \& Theory. 18. (1). Pp. 79-07. 2008

Vigoda-Gadot E. \& Mizrahi S. Israeli public sector performance: Citizens survey and National Assessment. Center for Public Policy and Management. University of Haifa. 2014

Wiley, Pugh \& Dietz. Service Climate Effects on Customer Attitudes: An Examination of Boundary Conditions.The Academy of Management Journal, Vol. 47, No. 1 .pp. 81-92 2004

Walker, J. Service climate in New Zealand English language centers. Journal of Educational Administration. 45. (3). Pp. 315- 337. 2007. Ll';1'

Wisniewski, M. Using SERVQUAL to assess customer satisfaction with public sector services. Managing Service Quality Vol. 11 PP. 380-388. 2001 